\title{
Post-Operative Therapy Rounds Section
}

National Cancer Institute

\section{Source}

National Cancer Institute. Post-Operative Therapy Rounds Section. NCI Thesaurus. Code C162551.

A form header for post-operative therapy round information. 